\title{
Mitigating the Hostile Environment: the role of the workplace in EU migrant experience of Brexit
}

Author: Renee Reichl Luthra, Department of Sociology, University of Essex

https://orcid.org/0000-0002-8502-2895

@ ReneeLuthra

\section{Biographical Note:}

Renee Luthra is senior lecturer in sociology and director of the Essex Centre for Migration Studies. Her teaching and research expertise include international migration, social stratification, education, and quantitative methods. Her current research examines ethnic inequality in childhood, education and the labour market the UK, Germany and the United States. Her first book (with co-authors Thomas Soehl and Roger Waldinger) Origins and Destinations: the making of the second generation, was published in 2018 by the Russell Sage Foundation.

\begin{abstract}
:
The rejection of free movement embodied in the 2016 Referendum vote created tremendous uncertainty regarding the immediate and future legal rights of EU nationals living in the UK. Drawing on interviews with EU staff and management at three universities, this paper asks how Brexit was experienced by highly skilled migrants in a sector reliant on EU migration, and the ways that employment in higher education buffered staff against its impact. Interviews reveal the ways that the Brexit vote disrupted previous perceptions of life in the UK, creating new feelings of vulnerability in terms of rights as well as public acceptance. Symbolic and practical support provided by management, as well as informal support from colleagues, cushioned EU employees against this shock. At the same time, employee satisfaction with employer response was shaped by perceptions of a neo-liberal turn within the University, with a subset of (primarily) academics expecting more personalised support and political involvement in the Brexit debate. Ironically, at the institutional level, the university with the most neo-liberal employment model was the most concerned and proactive in response to the Brexit vote, due to reliance on ready access to the EU to fulfil contingent labour contracts.
\end{abstract}

Keywords: Brexit, higher education, human resources, migration, policy

Word Count: 8,863 


\section{Introduction}

Brexit is the political issue of the moment in the UK. Yet while there is a multitude of writing about the attitudes and perceptions that brought the Referendum vote to pass (Goodwin and Milazzo 2017; Hobolt 2016; Mckenzie 2017), we are only just now able to see the consequences of the vote for non-EU UK residents (Botterill, McCollum, and Tyrrell 2019). At the time of writing (January 2020), EU nationals have experienced three and a half years of uncertainty about what Brexit will mean in legal terms for their rights as EU citizens. Emerging research demonstrates how the Referendum vote has "disrupted" migration and career trajectories for many EU nationals, exposing previously submerged legal, social and economic vulnerabilities (Lulle et al. 2019). While this body of work uncovers many individual level determinants of the impact of Brexit on the lived experiences of EU migrants in the UK, there is currently less understanding of the role that British institutions, many of them tasked with the actual bordering work of a hostile migration policy (Yuval-Davis et al. 2018), can have in mitigating or exacerbating this disruption and uncertainty. The goal of this paper is to address this gap, more specifically asking how institutions in higher education - a sector reliant on EU labour - respond to Brexit, and how this mediates the impact of Brexit on their EU employees. To answer this question, I draw on in-depth interviews with EU migrants and upper management at three universities in England.

Recent scholarship suggests that migrant experience of a hostile migration policy environment can vary across multiple levels: at the macro-, meso-, and micro-level (Erel and Ryan 2018). While Brexit negotiations are under the jurisdiction of national governance (the macro-level), the response of specific institutions such as schools, local service providers or workplaces to the decision can vary greatly over space and time (meso-level), potentially leading to very different experiences at the micro-level of individual EU migrants and their families. This paper contributes to a growing literature that examines the meso- and micro- 
level variation in the lived experiences of migration policy (Alba, Jiménez, \& Marrow, 2014; Doyle, 2018; Faist, 2010; Haas, 2010; McAreavey, 2017), providing new evidence on the way that employers can mediate or mitigate its impact on their workers.

In many ways, UK higher education is a sector which presents a "best case" scenario in terms of the potential mitigating impact of employers on the experience of a migration policy shock such as Brexit. First, many universities are highly internationalised and embedded in the European Union across multiple dimensions - in terms of research funding, student base, and staff recruitment - and thus it is very much in their interests to seek to counter the reputational, administrative, and organisational impacts of Brexit. Second, as major visa sponsors of third country migrants, both as employees and students, universities are experienced with and have an existing infrastructure to process and monitor staff under migration control, and are thus well equipped to incorporate EU employees into this existing system. Third, EU staff members in universities are among the most highly skilled EU migrants (Lulle et al. 2019). At the same time professional and academic staff members of the "mobile middle" differ in the degree to which international mobility is a choice or a demand in their career trajectories and future plans (Loacker and Śliwa 2015), as well as their perceptions of their own professional roles and the institutional mission of universities as their employer (Henkel 2005).

My interviews with EU academic and professional staff reveal how the run up to and Referendum vote decision presented a major disruption in their previous perceptions of the UK as a place to work and to live. Working in a university provided a significant buffer against this shock, a "bubble" where acceptance was both formally and informally signalled in individual and institutional interactions. Yet while all three universities provided symbolic and material support which was appreciated by employees, interviews also reveal the impact of perceptions of institutional mission on EU employee perception of management response. 
Two thirds of the interviews were conducted in the midst of the 2018 higher education pension strike, galvanising a latent dissatisfaction with the neo-liberalisation of the sector as a whole (Bergfeld 2018). Several of the academic interviewees were recently politicized and active in the industrial action, which in turn influenced perceptions of university management response to Brexit. Ironically, whereas some employees expected a more ideologicallydriven and political response to Brexit, perceiving its lack as a failing of the neo-liberal university, interviews with management reveal that it was precisely the demands of a neoliberal employment model, requiring access to an international labour pool for fixed-term contracts, which triggered the stronger Brexit response desired by more politicized employees.

\section{Reacting to Brexit: Experiences of EU migrants}

While not an immigration policy in itself, the decision to leave the European Union created tremendous uncertainty about the future rights of EU nationals living in the UK: the basic right to continued residence alongside rights to work, pensions, NHS health care, social benefits, and the rights of dependent children and spouses. The vote thus made visible existing vulnerabilities among EU migrants as well as created new ones (Burrell and Schweyher 2019), and my research mirrors previous accounts of how the Referendum vote exposed EU migrants to common experiences for third-country migrants which may have been invisible to them before - for instance the experience of monitoring from their employers (Manthorpe et al. 2018), navigating bureaucratic requirements to secure legal permanent residency or citizenship (McGhee, Moreh, and Vlachantoni 2017), and interactions with the Home Office (Yuval-Davis, Wemyss, and Cassidy 2017). The vote also created, or heightened, feelings of hostility and unwelcome, with respondents reporting an increase in awareness of anti-immigrant hate crimes (Rzepnikowska 2019) as well as a 
disruption of feelings of belonging and sense of personhood among long-standing EU residents in the UK (Guma and Dafydd Jones 2019).

Beyond a common feeling of shock and threat experienced by EU migrants following the Referendum vote, several scholars have also noted how "diverse histories and geographies of marginality and privilege shape responses to and impacts of Brexit" (Botterill et al. 2019:2). Many of these scholars have pointed to individual level characteristics, such as labour market position, social class (Lulle et al. 2019) and race (Benson and Lewis 2019), to argue that vulnerabilities to Brexit can align with existing stratification among EU migrants. Others note the importance of contextual characteristics in the lived experience of Brexit, for instance experiences of increased vulnerability in neighbourhoods perceived as dominated by white working class “others” (Rzepnikowska 2019) or in devolved regions such as Wales (Guma and Dafydd Jones 2019) as contrasted to the "Eurocity" of London (Favell 2011; Lulle et al. 2019). Yet despite this emerging literature on variation in the response of EU migrants to Brexit, there remains a gap in current understanding of how the workplace and specifically employers and managers can mediate the experience of Brexit for EU employees.

This is an important omission for several reasons. First, employers represent an important point of contact between migrants and the state, and employers are charged with much of the responsibility for ensuring legal right of residence at both the point of hiring and continued employment (Yuval-Davis et al. 2017). The costs of compliance to monitoring requirements are high, but losing the ability to sponsor visas can be disastrous, resulting in variation in the way that employers respond to these conflicting demands. Second, given the particularly high levels of employment of EU migrants in the UK (ONS 2019) for many EU migrants their workplace is a critical part of their lived experience (Burrell and Schweyher 2019) and an important source of social contact with British people, other migrants, and even co-ethnics. Finally, and particularly important for the hybrid public-private sector case of university 
employers here, we know that public service institutions, which have their own ethos and missions running counter to restrictive migration regimes, can actively resist, transform and mediate policy challenges arising from Brexit (Bachtler and Begg 2017) and create a more welcoming environment for migrants (Marrow, Helen 2009).

\section{Higher Education and EU Immigration}

As major employers in a hybrid public-private sector reliant on the EU for staff recruitment, funding and students, universities have both economic and symbolic concerns which are challenged by a hostile migration policy and economic uncertainty following from the Referendum vote. The percentage of EU academics rose from $12 \%$ to over $18 \%$ from 2004 to 2016 (Carpentier 2018), and EU nationals comprise a large proportion of technical and professional staff in Higher Education as well (UCEA 2017). Reflecting this recent shift, EU academic and professional staff are particularly concentrated among younger staff members and those on fixed-term contracts: as of 2016 one in four academics under the age of 50 is an EU national, and $42 \%$ are on fixed term contracts as compared to $30 \%$ of UK staff (UCEA 2017). Thus universities in the UK are particularly reliant on the EU for more junior staff members, and especially for the flexible academic workforce which is contingently employed.

Beyond staff recruitment, higher education in the UK is, in general, highly internationalized, with some arguing that commercial demands for "high value" fee-paying students transforms Universities into "migration industries" of their own (Beech 2018). A massive proportion of the UK's skilled migrant labour has been filtered through universities: $20 \%$ of the total student body comes from outside the UK, and student visas comprise $36 \%$ of all non-visit visas issues by the Home Office for the most recent year (2017) ${ }^{\mathrm{i}}$. EU membership also provides a direct and important revenue source for UK research, with varying impacts across 
different universities: the top 10 institutions accounted for nearly half $(47 \%)$ of the research income from EU government bodies in 2014-2015 - for all of these institutions, EU funding comprised more than $20 \%$ of their research income ${ }^{\mathrm{ii}}$. Thus some universities, particularly the most research intensive and high prestige, are more vulnerable to departure from the EU than those who rely more on teaching domestic students for funding. Reliance on EU funding is also mirrored by reliance on flexible academic labour to fulfil grant projects; access to the wider hiring pool of the EU is important in meeting demands for short-term, highly specialized labour.

Given their reliance on the EU, UK higher education institutions can be understood as mesolevel bodies, "migrant intermediaries" which need to maintain their own positive international "destination reputation" to attract skilled worker and student migrants (Harvey, Groutsis, and van den Broek 2018). This reputation is influenced by, but separate from, the national level destination country reputation; international offices (Beech, 2018) and the bilateral networks of academics and research teams signal welcome and attract future students and academic staff even within a hostile migration environment, potentially mitigating its cooling effect on skilled migration. In the face of anti-immigrant rhetoric in the media and a very delayed response to confirming the rights of EU migrants from the British government, universities can respond by ensuring their campuses are welcoming to international students and staff, that their international reputation is positive, and that they can continue to secure collaborations and funding from EU institutions and funding bodies.

Finally, migration intermediaries and employers organisations (in the case of higher education, Universities UK) have historically served a further role by not only moderating, but actually altering, the formation of national migration policy itself (Freeman 1995). This role can influence migration policy in both directions: there is substantial evidence that employers favour EU migration as a means to ensure a flexible labour force (McCollum and 
Findlay 2015); on the other hand, employers unions played an important role in closing migration from more recent EU accession countries Bulgaria and Romania in 2007 (Wright 2017). However, as institutions strongly embedded within the EU, as well as committed to a brand and mission of internationalism, individual higher education institutions and their lobbying body Universities UK, have been vocal in their opposition to any increase in barriers to movement for students or academics, activities which should impact their staff. ${ }^{\text {iii }}$

While the outward facing responses of universities to migration policy attract research attention, the focus of this paper is how the experiences of existing EU staff are shaped by the response of their employers to the uncertain policy environment following Brexit. We expect that EU employees in universities will be somewhat protected from the hostility and uncertainty which followed Brexit, due to the cosmopolitan work environment and their institutions' experience with existing immigration control. However we expect that academic staff, rather than professional staff, will pose a greater challenge for employers to recruit and retain. Academics are highly mobile workers (Bauder 2015), and the working lives of academic staff are likely to be compromised more by leaving the EU than the lives of professional staff: the completion of academic work is more reliant on access to EU funding, EU partnerships and mobility opportunities, and the ability to recruit high quality students and staff for research projects (Royal Society $2017^{\mathrm{iv}}$ ). We further anticipated differences across universities, with employees at the most prestigious institution feeling more protected against the fall-out of Brexit than those in Universities of more middling prestige.

\section{Immediate Fieldwork Environment}

Fieldwork for this project commenced at the end of January 2018, with interviews completed by October 2018. This was a period of substantial uncertainty in terms of the broader environment for EU migrants as well as sector specific volatility arising from a massive strike 
in higher education from 22 February to the 13 April 2018. In terms of the general social environment, the run up to and referendum decision accelerated hostile media coverage of European immigration (Fox, Moroşanu, and Szilassy 2012; Walter 2019), and although official reports of hate crimes show that societal hostility was sharpest directly following the vote in June $2016^{\mathrm{v}}$, qualitative accounts suggest underreporting and long-standing experiences of prejudice for many EU migrants (Rzepnikowska 2019). Rejection of free movement and immigration was a central part of the Leave campaign and polls conducted prior to and following the Referendum suggest that immigration was a top concern among those who voted to Leave (Arnorsson and Zoega 2018; Hobolt 2016) ${ }^{\mathrm{vi}}$.

It is important to note that the majority of interviews (28 of 37) were conducted between January and June 2018, before the government announced their plan to offer "pre-settled" and "settled" status to EU migrants with an expedited application process. ${ }^{\text {vii }}$ Prior to this, EU nationals and universities had only received the official statement on the future rights for EU nationals issued on 8 December 2017, and this statement was not binding, rather an indication pending on continued negotiations. Although EU migrants residing in the UK for at least five years were eligible to apply for indefinite leave to remain or citizenship, many lacked the uninterrupted residency required due to fluid migration trajectories with extended spells spent outside the country. Moreover those who had resided in the UK for less than five years could not immediately apply for any alternative form of official documentation of their right to live and work in the UK. My interviews reveal the challenges, even among highly educated academic and professional staff EU nationals, to move from a previous state of "deliberate indeterminancy" (McGhee et al. 2017) to securing permanent residency due to a lack of documentation and previous planning.

Beyond the negative societal and policy climate for EU migrants in general, the period of fieldwork was also marked by particularly volatile relationships between staff and 
management in higher education due to repeated industrial action which took place in Spring 2018. This was the largest strike ever in the sector, with high participation by staff members at all three institutions where fieldwork was held. Although the strike was specifically related to proposed changes to the University pension scheme, it increased the salience of long held dissatisfaction among UK academics with the commercialization, competition, and corporatization of the sector (Bergfeld 2018). The University and College Union (UCU), which led the strike, also simultaneously maintains campaigns to reduce workloads, support staff in further education, and to demand that universities assure the continued employment rights of EU staff following Brexit. ${ }^{\text {viii }}$ EU staff participation in all three universities was high, and their resulting politicization fused, for many, dissatisfaction with the higher education sector as a whole with their dissatisfaction and anxiety about how their institutions were handling Brexit.

\section{Methods}

\section{Higher Education Institutions}

The research involved interviews with management and EU academic and non-academic staff at three research active universities in England. The first research site, Mid Prestige University (MPU), is a university built during the 1960s, with a less selective, highly socioeconomically and ethnically diverse student body, including a substantial proportion of international students. The second research site, High Prestige University (HPU), is a Russell group member with a student body which is highly selected on academic achievement and substantially less socioeconomically diverse, although nearly half of its student population are international students (including EU nationals). The third research site is a 1960s university with a moderately selective student body and average proportion of international 
students. This university (MPUE) sets itself apart from the other two in its strong orientation towards the rest of Europe including several campuses on the continent.

EU nationals in these institutions are overrepresented among mid- and early career academics, in accordance with national trends, and EU nationals comprise a higher proportion of those on research only contracts, approximately $30 \%$ at all three institutions. Research only contracts may be long or short-term, but are strongly tied to grant income and are much less likely to be permanent than traditional teaching and research lectureships: $48 \%$ of HPU research only staff are on fixed term contracts, and $82 \%$ and $83 \%$ of MPU and MPUE, respectively. It is also very important to note that the structure of academic staff differs strongly between HPU and the mid prestige universities: 68\% of HPU academics are on research only contracts, in contrast with $10 \%$ at MPU and $14 \%$ at MPUE.

\section{Interviews}

A semi-structured interview guide was developed in autumn 2017 and used to obtain ethical approval for the study on 9 November 2017. The interview guide was piloted in December 2017 and amended. Thirty-seven semi-structured interviews were conducted between January and October 2018. At all three universities, the Vice-Chancellor's office was the first point of contact. For both MPU and MPUE an interview with the Vice-Chancellor was granted, and the office scheduled interviews with senior human resource officers (e.g. Head of HR, Head of Resourcing, and Head of Immigration and Compliance). For HPU the vice chancellor declined to be interviewed but helped arrange interviews with senior management. All staff interviews at HPU and academic interviews at MPU were obtained via initial contacts held in several departments at both universities with referrals from initial interviewees resulting in further interviews. At MPU and MPUE the human resource department sent an invitation email to professional staff via an existing EU national email 
list. MPUE also sent the invitation email to academic staff. Response was very high from this channel and potential interviewees were chosen to ensure coverage in terms of seniority of role, country of origin, and gender. All interviewees were members of the white majority from their origin countries, including management interviews, which consisted solely of white British. Further information of the interviewees are found in Table 1. All interviews were professionally transcribed and analysed using Nvivo version 11. Interviews with staff and management were initially analysed separately; afterwards interactions between staff and management response were also examined.

\section{Findings}

All interviewees were asked about perception of opportunities and challenges arising from the Referendum vote, as well their expectations and satisfaction with the government response to the vote. In addition, EU staff members were asked about their perception of the University response to Brexit, both in terms of efforts to support employees and in terms of efforts to mitigate any potential negative impact on the university arising from Brexit. University management, in contrast, was asked directly about their plans in both these areas. The interviews reveal the ways that the consequences of Brexit was experienced by EU employees, as well as the ways that the workplace environment and management response shaped this experience across a variety of domains.

\section{Vulnerability and Symbolic Support}

The Referendum vote presented a major disruption in the lives of EU nationals, and every single interviewee felt a sense of shock (if not surprise) when they heard of the result. As others have found, the degree of disruption varied across individuals depending on their life course and career plans as well as their degree of embeddedness in the UK, but for many of the respondents the run-up to the vote generated an awareness of their previously advantaged 
positions among foreign born workers in the UK and a new awareness of themselves as migrants, rather than as EU citizens in an EU country:

"It was really interesting because it was the first time I realised what it felt like potentially to wear a headscarf or to be Black, you know [...] all of a sudden, all of these White Europeans who had this wonderful life are all of a sudden saying, 'But people are not nice to me!' It's like, 'Welcome to the world!' - Laura, French/Italian, Senior Lecturer in Social Sciences, MPUE

Another common theme was the way that the Referendum vote transformed a sense of latent possibility to someday move back home or to a third country, a lack of desire to formalise their legal status, a feeling of ease about the UK as a home "for now" - into a perception of vulnerability which would force them to make concrete choices about their future (see also McGhee et al., 2017).Several interviewees mentioned explicitly that whereas before they might have monitored job openings in Europe casually, or spoken with their spouses about someday returning home, they now felt a sense of urgency that they would need to decide to stay or go in the near future, or end up "stuck" in the UK.

Despite this nearly universal feeling of vulnerability and disruption following the vote, most respondents also reported that their local friendship groups and university working environment created a "bubble" where their daily lives remained unaffected by hostility. Some of this feeling of safety stemmed from the general cosmopolitan environment of the University:

"I have never felt... sort of as an outsider in the UK... because...I think it is a lot to do with the University because it's a bit like a bubble... there's a lot of like minded people and a lot of my friends are within the University, so I think... my experience is not the general" - Iva, Latvian, Mid-career professional, MPU

Beyond the general benefits of a cosmopolitan working environment, however, essentially all of the interviewees reported direct actions taken by the University to increase their feelings of 
welcome, ranging from emails of solidarity from senior management following the vote to community building support:

"...there was a sense of support and solidary and definitely there was a whole 'We are European' campaign. People take pictures of teams, people hold up [signs with their nationality] for social media and stuff. And we did that in my department." - Sabine, German, Mid-career professional, MPUE

Thus interviews with EU employees revealed a recognition of the buffering effect of their working environment, many setting their experiences as a contrast with stories or media accounts of treatment elsewhere. In terms of the overall working environment following Brexit, EU staff members working in higher education considered themselves protected.

\section{Political Pressure and Outward Facing Statements}

In addition to influencing the immediate working environment for migrant staff, previous research has highlighted the role that employers can have in shaping a hostile migration policy directly through political lobbying (Freeman 1995). Whereas our interviews revealed a consensus opinion that the university environment protected staff from hostility following Brexit, there was considerable disagreement among interviewees in whether their university should take a political stance. In particular, academics who perceived the university's mission to be a leader in public debates were disappointed in the measured outward facing statements by all three of the Universities in this study. These interviewees held a view of themselves as independent academics and public intellectuals, rather than employees (several objected outright when I used the term) and believed the university had neglected its public function of officially weighing in on Brexit both before and after the Referendum vote:

"So concerning to Brexit is a lack of spine. They are just spineless. It's like any political statement, they are spineless. And I mean this also huge, a huge difference with the universities here [in Belgium], because they are run by Professors and they are truly independent institutions." - Pia, Belgian, Lecturer in Social Sciences, MPUE

There was a link drawn between perceptions of the neo-liberalisation of the sector as a whole, strongly related to the policitized environment during the pension strike, and perceptions of 
the university response to Brexit. Employees who were dissatisfied with the sector often expressed desire for a more independent, less commercialised, and more publically orientated institution, and this coloured their perception of management response to Brexit:

"I don't really experience the University institution as benign. You know, I think that it's become incredibly bureaucratic and... there's a sense in which the management is quite detached from the average member of staff and just that the kinds of targets that we're expected to reach in terms of output, administrative load, other sorts of things are just untenable for the best part. [...] And I don't think... I think that there's very limited discussion about that. I think Brexit is just one part of that. But I think it cuts across... you know, so many other things." - Jane, Irish, Senior Lecturer in Social Sciences, MPU

In contrast, some academics and most professional staff members were more comfortable, or at least more resigned, to their role as employees and their universities' need to maintain a neutral public response to Brexit. In particular these staff members cited the fact that the universities were located in larger pro-Leave regions and that some of the staff members might have themselves voted to leave:

"I think that the response was [hesitation] measured. I know that they can't take sides in this argument either, because I bet they were worried there were a number of people in the University who voted Brexit... so I guess the University can't make a political stand." Maria, Research Fellow in Social Sciences, Romanian, MPU

Contrasting these employee interviews with interviews with management, a strange paradox emerges. EU staff dissatisfied with UK universities as commercial enterprises desired stronger signalling on Brexit from management, largely framing this as an ethical, political stance. In contrast, interviews with management reveal that outward facing statements surrounding Brexit and political activism generally stemmed from commercial concerns, often deriving from the very same neo-liberalisation trends towards fixed-term and flexible labour criticised by dissatisfied EU staff:

“...there are certain roles where everything is time bound and it's money bound... if they wait three months, they fall behind on their research, their research becomes not viable, the 
whole project falls apart and that's where we've become so tied to the EU in that sense, that if they need somebody from France ...it's done, it's easy, they're there..." - George, Immigration Manager, $H P U$

Thus it is precisely the need for just-in-time academic and technical staff labour that prompts HPU's Head of HR to state "The immigration system will be the biggest challenge, clearly....and one of the key things we've determined is that we must, as an institution, seek to influence from the sector. (italics added)."

Whereas HPU, with its much larger research-only and grant-tied workforce, led in political lobbying, the Vice-Chancellor at MPU appeared most concerned with issues of branding and its "destination reputation" abroad, particularly in cultivating the international networks so central to the "migration industry" of the University (Beech 2018):

"I am travelling six or seven weeks a year now and very specifically to counteract any impression that Brexit means that we are becoming inwardly focused and not an outwardly focused global Britain." -Edward, Vice-Chancellor, $M P U$

While this sentiment was shared by management at the other two universities, MPU sets itself apart in its heavier reliance on international student recruitment: approximately $20 \%$ of those studying undergraduate first degrees at MPU are international, in contrast to $15 \%$ at MPUE and $12 \%$ at $\mathrm{HPU}^{\mathrm{ix}}$. The international composition of the student body is a major marketing point for this university, and MPU is also aggressively expanding its international outreach, including transnational education provision.

Regardless of its commercial motivation, however, these efforts are perceived and appreciated by EU staff, leading to a greater feeling of safety and support:

"But that in relation to [the impact of Brexit on] the University, I feel reasonably safe from that perspective ... I asked him [the VC] so what's the University doing [...] I do remember was that it was a very comprehensive satisfying answer that made me feel as if they have a 
very good brand and good idea of what to do in order to make sure that student recruitment numbers won't fall. The idea was mainly, don't ignore Europe, but don't focus on Europe specifically, focus more on international students, and developing the international base, and I thought, well yes, okay, this sounds alright." - Stan, Romanian, Early Career, MPU

\section{Monitoring and the Hostile Environment}

As other scholars have argued, much of the actual monitoring, "everyday bordering" work of the British hostile policy environment is outsourced to non-governmental actors (Yuval-

Davis et al. 2017). Universities are one of the largest users of skilled immigration visas in the UK, and visa sponsors are legally required to monitor staff on visas, including their work and attendance patterns, travel and residency requirements, local moves and compliance with health insurance fees. As experienced visa sponsors, all three of the institutions in this study had developed systems of monitoring both individual staff and student visa holders. Although such monitoring was not required of EU staff under free movement, following the Referendum vote all three institutions began communicating messages specifically to EU staff about their status and future compliance implications. All three institutions also sought to gather information on the current status of their EU national staff and their plans to acquire permanent residency or citizenship, where eligible. For many EU staff this was the first time they had any contact with university management about their nationality or any experience of the surveillance measures applied to visa holders.

While all three universities began monitoring EU employees shortly before or during the fieldwork period, the way that monitoring was perceived was related to the overall levels of trust and perception of the University. The issue arose much more frequently at MPUE, where the UCU industrial action was particularly fractious; many staff members were uncomfortable with these measures, and this dissatisfaction was expressed by both academic and professional staff: 
"this email from HR saying, can you verify [...] what your status is in Home Office terms [...] where you can tell that whoever wrote it was just doing this box-ticking exercise where they needed to find something but not realising that the amount of scaremongering that has been going on in the country and how this could be received by other people." - Amada, Portuguese, Middle Management, MPUE

Several academics also mentioned the Chris Heaton-Harris affair, when a minister of parliament wrote to all vice-chancellors in October 2017 requesting a list of all academics who were teaching on the subject of Brexit, together with copies of the syllabus and links to the course. Of the 59 universities that provided a response to the letter, 28 were cooperative, including one of the universities under study here, and this was known to staff and served to increase their feelings of mistrust ${ }^{1}$ and perception of exposure in a hostile migration policy environment. However, Amada goes on to acknowledge that University management was responsive to her concern about monitoring:

"I emailed the person in HR and copied in my boss to say I'm not comfortable answering these questions and why are you asking me this and straight away it was sent to senior management and the situation was sorted out."

As with political statements as a response to Brexit, the interests of management and employees aligned in keeping monitoring to a minimum, but with differing rationales. Management interviews from all three universities revealed concern about the potential administrative burden and compliance demands with the end of free movement. The existing visa categories for non-EU foreign nationals, Tier 2 for skilled professionals and Tier 4 for students, are notoriously cumbersome and expensive for both sponsors and visa holders. As described above visa sponsors are also required to check and validate right to work documents and monitor place of residence and attendance. So it is unsurprising that concern about increases in required administrative support and compliance costs were a major component of scenario planning for Brexit:

\footnotetext{
${ }^{1}$ https://www.bbc.co.uk/news/education-42431780
} 
"We are doing some scenario planning on... because it looks like they are going to have some sort of work permit application process for EU Nationals, so we're doing a worse case scenario if that turns out to be like the Tier 2 points base system. [Both Laughing I: The worst case indeed] Yeah. You know, actually how many man hours go into administering that process at the moment." - Shannon, HR Manager, MPU

Thus, monitoring is another area where the interests of management and employees coincide.

At the same time, interviews with both management and EU staff reveal the limitations of employers to protect staff against a hostile migration policy context. Universities require "Highly Trusted Sponsor" certification to streamline visas for non-EU students, leaving them with very little room to manoeuvre around burdensome monitoring and certification protocols. The lack of clear direction from the government following Brexit resulted in university management seeking a conservative route - both in terms of the reassurances it could provide to EU staff but also seeking to demonstrate clearly defined processes for monitoring EU staff. Both EU staff and management generally recognised that there were limitations to the power of universities, or any meso-level institution, in the level of response to monitoring they could attempt:

"I think that the cause is not the University, I think it's politics, so because UK politics is a complete mess, yes, like what, what can you expect them to do? Like hiring a lawyer, for instance, what can you lawyer up against at this stage? Nothing yet." - Wouter, Dutch, Lecturer in Social Sciences, HPU

\section{Bureaucracy and the Home Office}

Another theme to emerge from employee interviews was the challenges of formalising their status with the Home Office. The majority of interviews took place before the Home Office announced the EU settled status scheme, and many employees expressed confusion as well as fear over the arbitrariness of the department and its poor reputation. Many interviewees referred to their own direct experiences, or the experiences of friends or colleagues who had been unable to obtain advice on complex migration histories within their families (for 
instance, having one child born abroad and one in the UK, extensive periods away from the UK, sporadic work histories); many had had applications denied or documents withheld or lost. Even those without such first or secondhand experience mentioned media coverage of scandals of mistreatment by the Home Office.

Thus despite the high education level and native levels of English ability of nearly all of the staff interviewed, many felt afraid and intimidated by the forms for permanent residency and citizenship during the time of my fieldwork, before the alternatives for pre-settled and settledstatuses were announced. The cost, particularly for legal advice or applying for citizenship, was also considered prohibitive particularly for those with families. These bureaucratic and financial challenges were illustrated very well in the experience of Valerija, a Czech midcareer professional staff member at HPU with three children all born in the Czech Republic, who applied three different times to the Home Office for permanent residency status for herself and her family:

"It took us two and a half years, well, two years, and it cost us loads of money, over $£ 2000$ altogether because of the three applications, because of course it's not just the applications, it's all the paperwork which needs to be sorted extra and all the application fees..."

Both academic and non-academic staff were aware of efforts from the University to assist staff with applications. At the time of interviews all three universities had arranged for general meetings with an immigration attorney, and at both MPUE and MPU staff stated that the University was offering interest-free loans for naturalization. This support was meaningful for EU employees, and many stated that the level of support went beyond what they expected. Turning back to the case of Valerija referred to previously, she was one of the 700 people whom the Compliance Team at HPU personally assisted with their permanent residency form, a critical source of support for her in dealing with the bureaucratic consequences of Brexit: 
"so they had the head of the Compliance Team, which is quite a massive team in the University, because of all the schools visa and because of all staff visa coming from non-EU because they're much more complicated, and kind of to say, again, 'We are here, if you need help, we are here, come and discuss it.",

Indeed, many of the interviewees referred to universities experience as Tier II and Tier IV visa sponsors, and their highly international student and staff bodies, as enabling them to mediate the impacts of Brexit on their employees better than other employers might:

"And they care enough to try and translate [legal residency requirements] into a language that people who actually work here understand without having to have a law degree'. So that's always helpful. So, I felt quite good about that, to be honest. [I: Did you expect that?] I guess, in a way, as a very international organisation, I kind of would expect it. But at the same time... I can't say I'd really thought about getting that kind of information from the University as such." - Elsa, Belgian, Mid-career, $M P U$

Once again, those who were dissatisfied with the higher education sector as a whole also viewed the level of support with bureaucracy as insufficient, with many asserting that the University should have covered residency and citizenship fees as well. A common thread among these employees was of feeling expendable, and so the University would not bother to make real efforts to retain them:

"The uni is not, it is not a social enterprise, it's a business and wherever they see that they can save money and still get the same output I have no doubt in my mind that senior management will do that" - Bernd, German, Senior Lecturer in Biosciences, MPU

For employees that were happy with this arrangement, satisfaction was fairly high; the converse was true among staff that wanted the university to operate as a more social and communal organisation.

While the focus of this project was specifically on the employer and employee relationship, it is interesting to note that a communal and social organisation already exists within all three universities - namely the UCU - and this organisation had made strong statements in support of EU staff and sought to obtain public statements from management on continued rights of employment, and stability in the required qualifications for study and work, for EU nationals following Brexit. Potentially due to the fieldwork timing in the middle of the strike, however, 
the UCU was only mentioned in reference to the industrial action by management. Among employees, although several participated in the strike, only two reported direct interactions with the UCU specifically. It was generally noted that Brexit was pushed down the agenda of management during interviews as they were dealing with the turmoil around the strike.

\section{Discussion}

This paper has shown how EU academics and professional staff have responded to Brexit, and the way that the higher education workplace has buffered its impact on their lives. This paper contributes to an emerging literature that demonstrates how even highly skilled migrants, such as the EU professionals and academics interviewed for this project, experience vulnerability and a feeling of unwelcome in response to the 2016 Referendum. As in other research of EU nationals post-Brexit, our interviewees reported increased hostility, both first and secondhand, feelings of threat from negative media portrayals, and have been prompted to profoundly reconsider their professional trajectories as a consequence of the Referendum vote. Equally important, we have documented how even highly educated and completely fluent English speaking EU migrants can struggle with the bureaucracy of UK residency and citizenship requirements. This project further adds to the extant literature on migrant response to the hostile environment by showing how the experiences of surveillance and monitoring by employers, long a feature of life for non-EU employees and students in the UK, are experienced by EU migrants following Brexit as well.

This paper also presents one of the first accounts of the way that these experiences are mitigated by a supportive workplace environment. As already stated at the onset, universities likely represent a "best case" as employers who are particularly well suited to address concerns arising from Brexit, given their highly international workforce and student base and extensive experience as visa sponsors. By focusing on the higher education sector, we are 
able to observe various facets of the role employers can play as meso-level mediators of a hostile migration policy environment: EU staff reported appreciation for the supportive and cosmopolitan environment of their universities, for the practical actions taken by management to provide access to migration information tailored to their concerns, for their response to employee concerns about monitoring, and for the provision of assistance with applications for residency and citizenship. Although universities may be uniquely well placed to provide all of these elements, many of them, such as showing symbolic support for EU employees, are low cost and could be adopted widely.

Despite this general positive picture of the University creating a "bubble" for employees which protected them from displays of public xenophobia and provided support in a changing migration policy climate, there was substantial variation in the expectations and satisfaction of EU staff. We anticipated that EU academics might have higher expectations, and be more difficult to retain than professional staff; however perceptions of university mission emerged as the more important factor in predicting satisfaction with management response.

Dissatisfied employees were more likely to see the University as a public voice in policy debate, and to see themselves as independent academics or public sector professionals rather than employees. Resentment of the neo-liberalisation of higher education in general, exacerbated by the industrial action in Spring 2018, particularly coloured academic perceptions of university response during the fieldwork period.

Ironically, while politicized and disaffected employees wanted a stronger political voice and greater protection from the University in light of their of rejection of a neo-liberal University model, it was the pressures set by the demand for a contingent workforce and the need to maintain a positive immigration reputation, in other words a response to specifically market demands, which resulted in a stronger response from university employers. The degree to which universities will seek to protect employees from hostile migration policy does not 
primarily hinge on issues of mission or ethos - as has been found in previous research with public sector bureaucrats (Marrow 2009) - but rather appeared to reflect the degree to which restrictive policies interact with the local adoption of neo-liberal employment strategies. Thus, although employees at the most prestigious university did, as expected, feel more satisfied with their institution's response to Brexit, this was due to attempts to mitigate vulnerability arising from reliance on grant income and contingent staff, rather than a show of strength.

Indeed, this study reveals the limitations of employers in their ability to manoeuvre around the heavy bureaucracy and restrictions implemented by the state. As a sector highly dependent on successfully securing visas for both employees and students, higher education institutions are forced to bear heavy administrative costs to avoid running afoul of immigration law and losing the ability to sponsor the visas are required. Although EU citizens were not formally part of this system at the time of the fieldwork for this paper, the lack of a clear policy for EU migrants post-Brexit placed universities in a precarious position, both unable to offer security to existing EU staff and needing to closely monitor them, at the same time attempting to plan for a disruption to both research and tuition funding, the magnitude of which continues to be unknown at the time of writing.

In conclusion, this paper shows the possibility, but also the limitation of workplace and employer efforts as a meso-level influence in the experience of migration policy for migrant employees. Focusing on this "best case" shows a wide range of potential dimensions of support that employers can provide, but also reveals the limitations of employers within even a large and influential sector in protecting their employees from a hostile environment. Future work is planned to compare the experiences recorded here with those of EU employees of various skill levels in the National Health Service, another major EU-reliant employer in a hybrid public-private sector. Another fruitful avenue would be to examine how employees in 
more agile and resource-rich private sector firms responded to the uncertain policy

environment of Brexit, and whether their employees might have been more difficult to retain then the middling transnational professionals and academic staff interviewed here.

Acknowledgments: This work was supported by the Society for Research in Higher Education under Grant RA1746 and the ESRC Research Centre for Micro-Social Change under Grant ES/L009153/1.. The paper also benefited from helpful feedback from Tina Haux, Kate Choi, Erin Hamilton, Neli Demireva, Yannig Luthra and participants at the University of Essex Centre for Migration Studies 2018 Research Workshop.

\footnotetext{
i https://www.gov.uk/government/publications/immigration-statistics-october-to-december-2017/summaryof-latest-statistics

ii https://royalsociety.org/ /media/policy/Publications/2017/2017-05-technopolis-role-of-EU-fundingreport.PDF

iii See for instance policy advice and analysis on a dedicated Universities UK webpage

https://www.universitiesuk.ac.uk/policy-and-analysis/brexit

iv https://royalsociety.org/ /media/policy/Publications/2017/2017-05-technopolis-role-of-EU-fundingreport.PDF

"https://assets.publishing.service.gov.uk/government/uploads/system/uploads/attachment data/file/748598/ hate-crime-1718-hosb2018.pdf

vi http://csi.nuff.ox.ac.uk/?p=1153

vii https://www.gov.uk/settled-status-eu-citizens-families/applying-for-settled-status

viii See for instance https://www.ucu.org.uk/we-are-international
}

\section{REFERENCES}

Andrews, Penny. 2019. The compliant environment: conformity, data processing and increasing inequality in UK Higher Education. Online Information Review 43(6): 1063-1079.

Arnorsson, Agust and Gylfi Zoega. 2018. 'On the Causes of Brexit'. European Journal of Political Economy 55: 301-323.

Bachtler, John and lain Begg. 2017. 'Cohesion Policy after Brexit: The Economic, Social and Institutional Challenges'. Journal of Social Policy 46(4):745-63.

Bauder, Harald. 2015. 'The International Mobility of Academics: A Labour Market Perspective'. International Migration 53(1):83-96.

Beech, Suzanne E. 2018. 'Adapting to Change in the Higher Education System: International Student Mobility as a Migration Industry'. Journal of Ethnic and Migration Studies 44(4):610-25.

Benson, Michaela and Chantelle Lewis. 2019. 'Brexit, British People of Colour in the EU-27 and Everyday Racism in Britain and Europe'. Ethnic and Racial Studies 42(13) 1-18. 
Bergfeld, Mark. 2018. "'Do You Believe in Life after Work?” The University and College Union Strike in Britain'. Transfer: European Review of Labour and Research 24(2):233-36.

Botterill, Kate, David McCollum, and Naomi Tyrrell. 2019. 'Negotiating Brexit: Migrant Spatialities and Identities in a Changing Europe'. Population, Space and Place 25(1):e2216.

Burrell, Kathy and Mateus Schweyher. 2019. 'Conditional Citizens and Hostile Environments: Polish Migrants in Pre-Brexit Britain'. Geoforum 106:193-201.

Carpentier, Vincent. 2018. 'Expansion and Differentiation in Higher Education: The Historical Trajectories of the UK, the USA and France'. Centre for Global Higher Education Working Paper 33.

Erel, Umut and Louise Ryan. 2018. 'Migrant Capitals: Proposing a Multi-Level Spatio-Temporal Analytical Framework'. Sociology 53(2):246-63.

Favell, Adrian. 2011. Eurostars and Eurocities: Free Movement and Mobility in an Integrating Europe. Vol. 56. John Wiley \& Sons.

Fox, Jon E., Laura Moroşanu, and Eszter Szilassy. 2012. 'The Racialization of the New European Migration to the UK'. Sociology 46(4):680-95.

Freeman, Gary P. 1995. 'Modes of Immigration Politics in Liberal Democratic States'. The International Migration Review 29(4):881-902.

Goodwin, Matthew and Caitlin Milazzo. 2017. 'Taking Back Control? Investigating the Role of Immigration in the 2016 Vote for Brexit'. The British Journal of Politics and International Relations 19(3):450-64.

Guma, Taulant and Rhys Dafydd Jones. 2019. "'Where Are We Going to Go Now?” European Union Migrants' Experiences of Hostility, Anxiety, and (Non-) Belonging during Brexit'. Population, Space and Place 25(1):e2198.

Harvey, William S., Dimitria Groutsis, and Diane van den Broek. 2018. 'Intermediaries and Destination Reputations: Explaining Flows of Skilled Migration'. Journal of Ethnic and Migration Studies 44(4):644-62.

Henkel, Mary. 2005. 'Academic Identity and Autonomy in a Changing Policy Environment'. Higher Education 49(1-2):155-76.

Hobolt, Sara B. 2016. 'The Brexit Vote: A Divided Nation, a Divided Continent'. Journal of European Public Policy 23(9):1259-77.

Loacker, Bernadette and Martyna Śliwa. 2015. “"Moving to Stay in the Same Place?" Academics and Theatrical Artists as Exemplars of the "Mobile Middle"'. Organization 23(5):657-79.

Lulle, Aija, Russell King, Veronika Dvorakova, and Aleksandra Szkudlarek. 2019. 'Between Disruptions and Connections: "New" European Union Migrants in the United Kingdom before and after the Brexit'. Population, Space and Place 25(1):e2200. 
Manthorpe, Jill, Jess Harris, Martin Stevens, and Jo Moriarty. 2018. “'We'Re Effectively Becoming Immigration Officers": Social Care Managers' Experiences of the Risk Work of Employing Migrant Care Workers'. Health, Risk \& Society 20(3-4):113-25.

Marrow, Helen. 2009. 'Immigrant Bureaucratic Incorporation: The Dual Roles of Professional Missions and Government Policies'. American Sociological Review 74(5):756-76.

McCollum, David and Allan Findlay. 2015. "Flexible'Workers for 'Flexible'Jobs? The Labour Market Function of A8 Migrant Labour in the UK'. Work, Employment and Society 29(3):427-443.

McGhee, Derek, Chris Moreh, and Athina Vlachantoni. 2017. 'An "Undeliberate Determinacy"? The Changing Migration Strategies of Polish Migrants in the UK in Times of Brexit'. Journal of Ethnic and Migration Studies 43(13):2109-30.

Mckenzie, Lisa. 2017. 'The Class Politics of Prejudice: Brexit and the Land of No-hope and Glory'. The British Journal of Sociology 68:S265-80.

ONS. 2019. UK and Non-UK People in the Labour Market: August 2019. Labour Market Overview Statistical Bulletin 2019.

Rzepnikowska, Alina. 2019. 'Racism and Xenophobia Experienced by Polish Migrants in the UK before and after Brexit Vote'. Journal of Ethnic and Migration Studies 45(1):61-77.

UCEA. 2017. Response from the Universities and Colleges Employers Association (UCEA). https://www.ucea.ac.uk/library/consultation-responses/immigration-and-brexitconsultations/

Walter, Stefanie. 2019. 'Better off without You? How the British Media Portrayed EU Citizens in Brexit News'. The International Journal of Press/Politics 24(2):210-32.

Wright, Chris F. 2017. 'Employer Organizations and Labour Immigration Policy in Australia and the United Kingdom: The Power of Political Salience and Social Institutional Legacies'. British Journal of Industrial Relations 55(2):347-71.

Yuval-Davis, Nira, Georgie Wemyss, and Kathryn Cassidy. 2017. 'Everyday Bordering, Belonging and the Reorientation of British Immigration Legislation'. Sociology 52(2):228-44. 